\title{
Touch-Point Mathematics Instruction for Children with Autism Spectrum Disorder: A Systematic Literature Review
}

Nur Amira Yusaini, Siti Mistima Maat, Roslinda Rosli

To Link this Article: http://dx.doi.org/10.6007/IJARBSS/v9-i3/5730

DOI: $10.6007 /$ IJARBSS/v9-i3/5730

Received: 04 Feb 2019, Revised: 23 Feb 2019, Accepted: 21 March 2019

Published Online: 03 April 2019

In-Text Citation: (Yusaini, Maat, \& Rosli, 2019)

To Cite this Article: Yusaini, N. A., Maat, S. M., \& Rosli, R. (2019). Touch-Point Mathematics Instruction for Children with Autism Spectrum Disorder: A Systematic Literature Review. International Journal of Academic Research in Business and Social Sciences, 9(3), 609-625.

\section{Copyright: (C) 2019 The Author(s)}

Published by Human Resource Management Academic Research Society (www.hrmars.com)

This article is published under the Creative Commons Attribution (CC BY 4.0) license. Anyone may reproduce, distribute, translate and create derivative works of this article (for both commercial and non-commercial purposes), subject to full attribution to the original publication and authors. The full terms of this license may be seen

at: http://creativecommons.org/licences/by/4.0/legalcode

Vol. 9, No. 3, 2019, Pg. 609 - 625

Full Terms \& Conditions of access and use can be found at http://hrmars.com/index.php/pages/detail/publication-ethics 


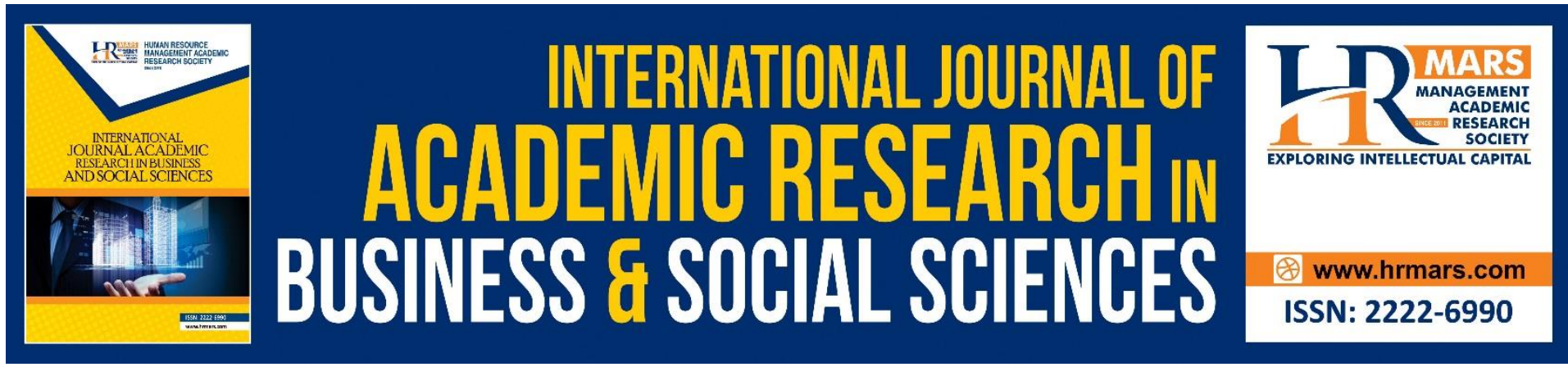

\title{
Touch-Point Mathematics Instruction for Children with Autism Spectrum Disorder: A Systematic Literature Review
}

\author{
Nur Amira Yusaini, Siti Mistima Maat, Roslinda Rosli \\ Faculty of Education, National University of Malaysia \\ Email: P89375@siswa.ukm.edu.my, sitimistima@ukm.edu.my, roslinda@ukm.edu.my
}

\begin{abstract}
Children with Autism Spectrum Disorder (ASD) often face some problems in mastering basic numeracy skills. A touch point is a multisensory method that has been introduced especially for children with ASD as it is one of a proven way of improving their achievement in mathematics. Thus, this systematic literature review is conducted (a) to identify the characteristics of participants and suitability of touch points interventions based on the characteristics of children with ASD and (b) to evaluate the effectiveness of touch point interventions in improving the achievement of children with ASD. Overall, the empirical studies indicated that the touch point mathematics instruction commonly used in teaching primary school students on basic mathematical knowledge such as numbers and arithmetical operation skills. Hence, the touch point was effective in helping teachers to help children with ASD in learning basic mathematics. Implications are discussed.
\end{abstract}

Keywords: Autism Spectrum Disorder (Asd), Mathematics Interventions, Numeracy, Hands-On Approach.

\section{INTRODUCTION}

Autism Spectrum Disorder (ASD) is defined as a lifelong disability that has been characterized by impairments in communication, social interaction as well as limited and repetitive behaviors and interests (American Psychological Association [APA], 2013). According to Schmidt and Bonds-Raacke (2013), ASD is a type of disorder that includes individuals with autism and Asperger syndrome also extensive of a developmental disorder. Individuals with autism often experienced three types of impairments wherein includes verbal and non-verbal communication, socialization, and distraction to environmental changes (Burney, 2015; McCrimmon \& Yule, 2017; O’Malley et al., 2014; Schmidt \& Bonds-Raacke, 2013; Su et al., 2012).

The disability of ASD can adversely affect the education performance of children with autism (Burney, 2015; O'Malley et al., 2014; Schmidt \& Bonds-Raacke, 2013) which in turn will cause them to be left behind by their peers. The problems that enormously affect children with autism are mastering in basic mathematical skills (Burney, 2015; O'Malley et al., 2014), reading, writing, speaking and also their ability in completing tasks individually (Burton et al., 
2013; Holifield et al., 2010; O'Malley et al,. 2014). This education and skills are an essential element for them to live life and to build the foundation for more complex numeracy skills (Jowett et al., 2012; O'Malley et al., 2014). The mastery of basic skills in mathematics is a part of critical skills that can determine the individuals' achievement in mathematics (Royer, 1999). Basic skills in mathematics include number identification, addition, subtraction, multiplication, and division involving single digit number, problem-solving, learning about money and time units (Berry, 2012; Yıkmış, 2016).

According to Yıkmış (2016), the addition process involving single-digit numbers and obtaining two digit numbers also known as essential mathematical skill. However, if children's early understanding of mathematical concepts is not well developed, they will have difficulty in understanding the next level of mathematics in primary school. This will lead most of ASD's children with average and inferior intellectual development struggle in order to understand the basic mathematical skills (Burney, 2015) yet showing continuous difficulty in basic calculation and problem solving which in turns give low standards of mathematics achievement (Browder et al., 2012; O’Malley et al., 2014; Spooner et al,. 2018).

\section{Numeracy skills for children with ASD}

Numeracy can be defined as the efficiency in performing basic mathematical operations and the ability to apply such knowledge in the context of real life (NCTM 2012; KPM 2010). Siti Rahaimah (2014) states numeracy is an essential topic of mathematics in primary and secondary school. Numeracy is the basis for the continuation of mathematical learning at the next level. Apart from that, numeracy is also more geared towards the ability to use mathematical knowledge and skills in solving problems (Asiahwati, 2015; Geary, 2011; Geiger et al., 2013; Jordan et al.,. 2009; Sarama \& Clements, 2008). The significance of numeracy should be given attention to the early stages of learning, especially for the basic skills that the children should be required in mathematics (Siti Rahaimah, 2014).

Therefore, various forms of early mathematical interventions are often carried out to aim in helping the mathematics achievement of children with ASD at all levels and to avoid them having problems in learning mathematics (Shanley et al., 2013). Several practical teaching skills showed to be highly effective for children with ASD. Among them are the delivery of systematic and explicit directions, peer-to-peer learning and visual display (Besler \& Kurt, 2016; O'Malley et al., 2014). Besler and Kurt (2016) also point out that one of the most effective teaching methods is to show how the skills are demonstrated. Nevertheless, the rapid adoption of computer-based technology in the classroom today makes concrete materials as teaching aids less used although, for decades, these materials are believed to help students with learning disabilities (Cihak \& Foust, 2008; Satsangi et al., 2016). As a result, children with ASD often make writing skills as a challenging skill (Zajic et al., 2016). Still, Burney (2015) and Cihak and Foust (2008) affirmed that students could even develop basic mathematical concepts using concrete materials.

\section{Touchpoints intervention facilitates children with ASD in mastering numeracy skill}

Behind the use of rapid technology as a teaching aid tools (Satsangi et al., 2016), more and more studies have been made on new and innovative interventions such as TouchMath programme (Bullock et al., 1989) also known as a touch point. Touchpoint is a multisensory method that involves visual, auditory and tactile learning (Calik \& Kargin, 2010) especially for 
children with disabilities and had ASD (Calik \& Kargin, 2010; Cihak \& Foust, 2008; Simon \& Hanrahan, 2004; Waters \& Boon, 2011).

This method use dot-notation to teach mathematical skills (Cihak \& Foust, 2008; Simon \& Hanrahan 2004; Waters \& Boon 2011) which the children mark the points that appear on the numbers and dots in the circle while looking at the number (visual) and calculate the amount (auditory) using a pencil (tactile). The children are taught to count the points found on each number representing the actual quantity of the number (Berry, 2012; Waters \& Boon, 2011) as shown in Figure 1.

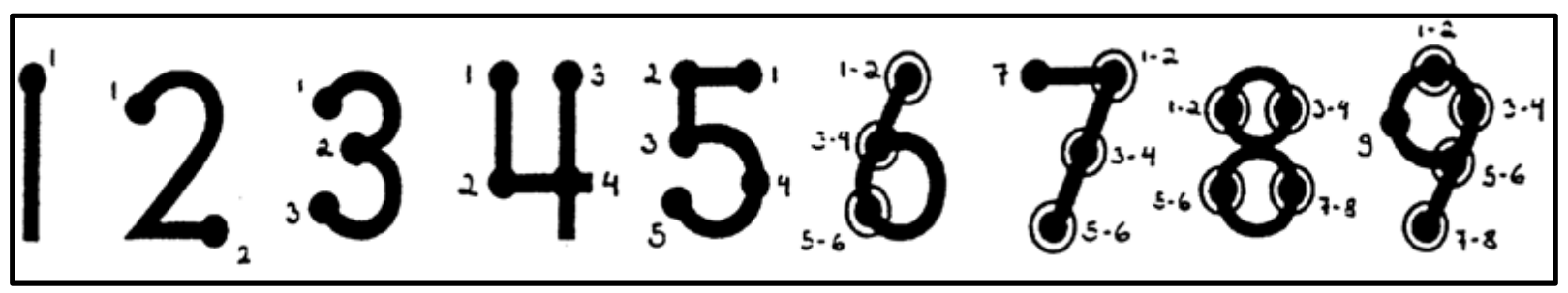

Figure 1. Touchpoints system representation developed by Bullock et al. (1989)

This method has showed a few results with positive effects in improving the student's performance with or without problems in understanding the basic concepts of mathematics (Waters \& Boon 2011). It has been proven successful in solving addition and subtraction problems with single digit (Avant \& Heller, 2011; Berry, 2012; Cihak \& Foust, 2008; Rudolph, 2008; Wisniewski \& Smith, 2002) and two digits (Calik \& Kargin 2010; Simon \& Hanrahan, 2004; Waters \& Boon, 2011; Yıkmış, 2016) specifically for children with ASD who confront with problems in learning basic numeracy skills.

The necessity of early intervention was to address the learning problems they faced. Ping Yee and Mohd Ali (2008) states that one of the purposes of early intervention is to enhance the confidence level of children with ASD to apply basic numeracy skills in everyday life. Therefore, to ensure their basic mathematical knowledge is at the finest level, interventions need to be carried out to ascertain the rationality of teaching methods. Furthermore, the best way to help children with learning disabilities is by using concrete materials (Berry, 2012; Calik \& Kargin, 2010; Cihak \& Foust, 2008; Simon \& Hanrahan, 2004; Yıkmış, 2016) considering the instructions given with the use of concrete materials as manipulative tools facilitate the children with ASD to understand the concepts of mathematical skills learned. Thus, a touch point is chosen as an intervention as it is a multisensory method that applies to children with ASD.

There are three recent literature syntheses have reviewed on mathematics intervention for the same population. First, Cindy et al. (2016) discussed mathematics intervention that focused on students with ASD and the studies are within the area. Thirty studies for the academic content area that have been published between the year of 1987 and 2015 were included as studies that meet research criteria. Second, King et al. (2016) have reviewed on mathematics intervention studies which also focused on children with ASD and intellectual disabilities involving 14 academic studies that were published around 1988 until 2014. Third, Lemons et al. (2015) have reviewed mathematics intervention for both children and adult with ASD and down syndrome. Lemons et al. (2015) studies involved nine academic studies between the years of 1989 and 2012. This present study is emphasized on the review on mathematics intervention using touch points, determine additional studies, classify touch 
points according to the characteristics of the study participants to identify the suitability of interventions and the effectiveness in improving the achievement of children with ASD.

\section{Research questions}

The research questions that guided this systematic literature review are: What kind of studies published in journals that engaged touch points intervention to assess children with ASD? Specifically, the aims of this study are:

(a) to identify the characteristics of participants, findings and suitability of touch point intervention based on the characteristics of children with ASD and;

(b) to assess the effectiveness of touch point intervention in improving the mathematics achievement of children with ASD.

\section{METHODOLOGY}

The method used to conduct this review is PRISMA (Preferred Reporting Items for Systematic Review and Meta-Analyses). In short, PRISMA is a form of reporting for systematic review and meta-analysis that focus on reporting survey to assess random trials but also used as a basis for reporting systematic review, particularly for intervention assessment.

\section{Inclusion Criteria}

Studies with the following criteria are included: (a) touch point intervention with at least one dependent measure of mathematics-related outcomes is evaluated, (b) involved at least one participant with ASD by assessing the effectiveness of touch point intervention on the experimental group or single-subject design and (c) used an experimental design. The findings with a focus of mathematical accuracy are accepted (e.g., the percentage of correct responses).

\section{Search Procedures}

We identified the relevant articles through search procedures consisting of four phases (see Figure 2). Specifically, we conducted (1) electronics database search, (2) a review of recent systematics journals, (3) a hand search of relevant journals and (4) an ancestral search of identified articles.

First, three searches of databases are used, Educational Resources in Education Clearinghouse (ERIC), SAGE Journals dan Google Scholar. The first search used the terms ("autism" OR "autism*") AND ("intervention" OR "mathematics" OR "math" OR "numeracy" OR "arithmetic" OR "addition" OR "subtraction" OR "algebra" OR "count"). While the other search replaced the second set of terms with "Touch-Points" OR "TouchMath" OR "multisensory approach." At this phase, the search is limited to the first ten years of publishing which is from 2008 to 2018. All of the reviewed article journals yield 527 records and 12 articles with full text. Five of these met the inclusion criteria. 


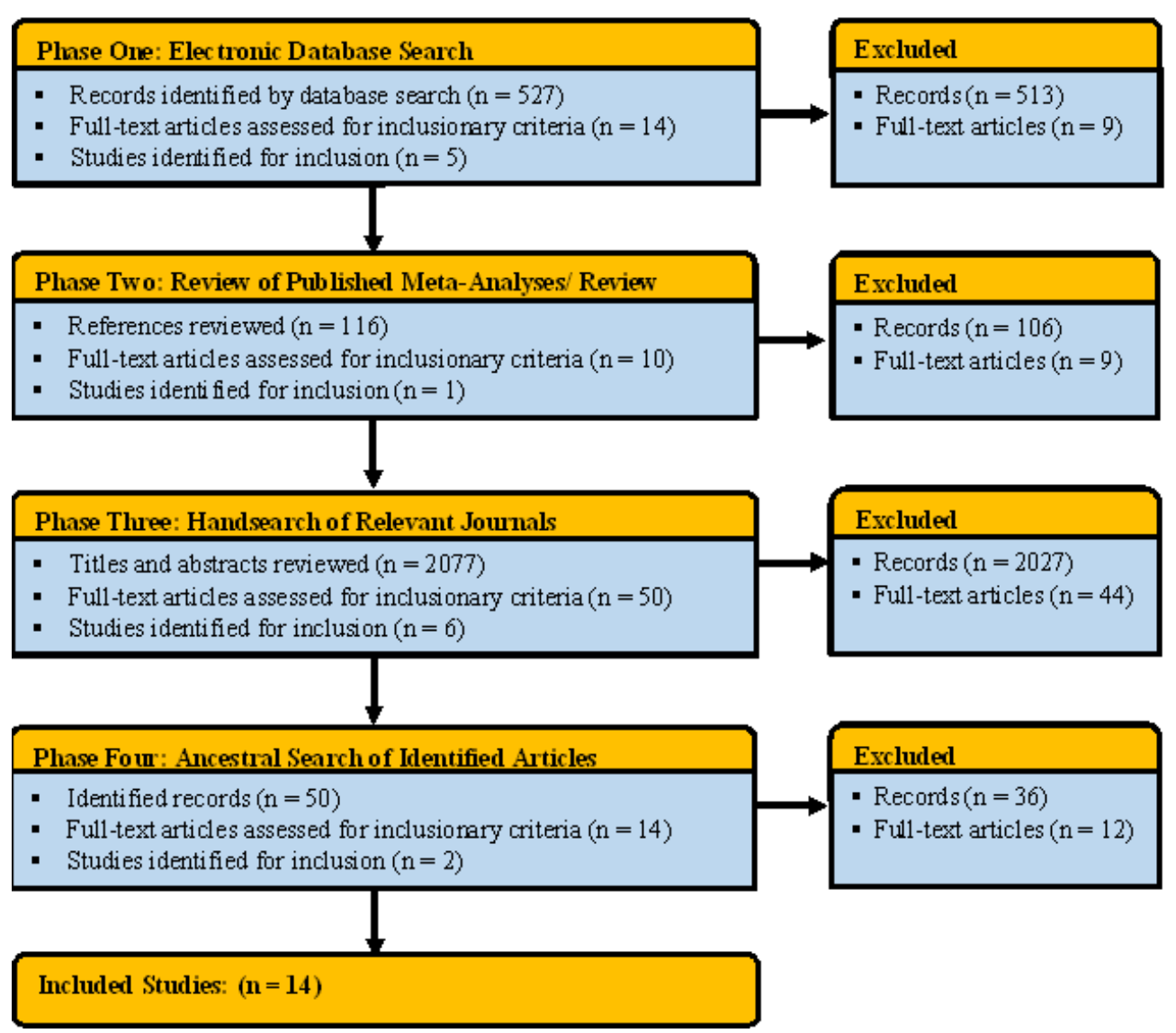

Figure 2 Study identification procedures

Second, the list of seven published recent reviews related to mathematics intervention for children with ASD is reviewed (Aydemir, 2015; Burney, 2015; Cihak \& Foust, 2008; Gevarter et al., 2016; Lemons et al., 2015; Spooner et al., 2018; Whalon et al., 2015). From the search of 116 journal articles, ten articles with full text covering technology-based interventions, concrete materials, and touch points methods are chosen. One of these met the inclusion criteria.

Third, a hand search of relevant journal articles according to the year published between 1980 to 2018 is conducted for the following journals: American Journal of Intellectual and Developmental Disabilities, Education and Treatment of Children, Developmental Neuropsychology, International Journal of Special Education, Journal of Intellectual Disability Research, Journal of Special Education, Exceptional Children, Remedial and Special Education, Journal on Developmental Disabilities, Research and Practice for Person with Severe Disabilities dan Research in Developmental Disabilities. At this stage, the search is broadened to the year of 1980 until 2018. The year 1980 was used because that was the first year autism was a separate diagnostic category in the Diagnostic and Statistical Manual of Mental Disorder (Gevarter et al., 2016). The search at this phase yield 2,077 journal articles and 50 articles with full text are identified. Two of these met the inclusion criteria. Fourth, an ancestral search by reviewing the references of articles were identified up to this point of search. From the pursuit of 50 journal articles, 14 articles were identified that focused 
on mathematical interventions using the touch point method for children with ASD. All of these nine articles are published between the year of 1983 and 2016 identified for inclusion.

\section{Coding Procedures}

The information for each of the study has been categorized based on the variables: participants, setting, instrument, mathematical skills focused and the findings. The coding procedures for participants of the study are based on items: age, gender, ASD level and level of mathematical performance. While the coding procedures for setting include the location of research has been conducted in general (e.g., school) or specific (e.g., classroom in a school) and the intervention situation (e.g., group or study). Instrument encoding includes all manipulative materials used such as touch point worksheets and additional equipment as complementary to convey instructions. Mathematical skills focused are a mathematical skill developed using intervention to improve students' mathematical performance (e.g., addition, subtraction, multiplication, and money). The coding procedures for findings are to measure the mathematical accuracy (e.g., percentages of correct responses).

\section{FINDINGS AND DISCUSSION}

In the following section, the discussion of the research findings focused on the previous research that has been included in Table 1 for answering the research question.

\section{Characteristics of participants and suitability of touch point interventions}

Fourteen intervention studies using touchpoint have been selected meet the inclusion criteria are between the years of 1983 and 2016 sorted descending by year as shown in Table 1 . All of the studies involved 239 participants with ASD with a mean age of 7 (from 5 years old to 9 years old). Among the 14 studies selected, ten journal articles conducted a single-subject design with 41 participants in total (24 males, 17 females) and the rest were held using group experimental design with 198 participants in total. All of these studies with the single-subject design carried out intervention for 15 to 180 minutes individually. While group experimental design was conducting group intervention sessions either with 3 to 4 participants in a group or whole-class involvement. Most of the interventions sessions take place in a class or separate room to prevent any interference.

All the studies used intervention focused on improving the basic mathematical skills of children with ASD on addition and subtraction. Ten studies focused on addition skills in which eight studies (Akmanoglu \& Batu, 2004; Avant \& Heller, 2011; Calik \& Kargin, 2010; Cihak \& Foust, 2008; Fletcher et al., 2010; Rudolph, 2008; Wisniewski \& Smith, 2002; Yıkmış, 2016) investigated addition with one digit and two studies were in addition with single and double-digits (Simon \& Hanrahan, 2004; Strand, 2003). On the other hand, there is a study (Waters \& Boon, 2011) used touch points intervention to focus on subtraction skill to learn about money. The remaining three studies focused on both addition and subtraction skills with two studies conducted single digit addition and subtraction (Berry, 2012; Thornton et al., 1983), and one study conducted the single and double-digit addition and subtraction (Scott 1993). Based on the characteristics of the participants involved in this study, it can be seen that the primary school students were the most participants involved. This finding suggested that the touch point method was used in teaching the basic mathematical knowledge to primary school students. However, due to the limited number of high-quality studies, we have not been able to identify the suitability of touch point intervention based on the 
characteristics of ASD's children and evaluate the effectiveness of touch point intervention in improving mathematical achievement for them accurately. 
Table 1. Descriptions of participants, settings, focused skills, instruments, and findings

\begin{tabular}{|c|c|c|c|c|c|}
\hline $\begin{array}{l}\text { Researcher } \\
\text { (s) }\end{array}$ & Participants & Settings & Focused skills & Instruments & Findings \\
\hline $\begin{array}{l}\text { Yikmis } \\
(2016)\end{array}$ & $\begin{array}{l}\text { Three males }(8-10) \text {, } \\
\text { diagnosed with ASD. }\end{array}$ & $\begin{array}{l}\text { Intervention held in a } \\
\text { class }(4 \times 3 \mathrm{~m}) \\
\text { individually. } \\
\text { Practitioner and } \\
\text { participant sat face to } \\
\text { face. There was no other } \\
\text { person in the classroom } \\
\text { except the practitioner } \\
\text { and participant. }\end{array}$ & $\begin{array}{l}\text { Single-digit addition } \\
\text { that has a single-digit } \\
\text { sum. }\end{array}$ & $\begin{array}{l}\text { A video camera was } \\
\text { used to record and } \\
\text { worksheets with ten } \\
\text { addition questions with } \\
\text { touchpoint strategy. }\end{array}$ & $\begin{array}{l}\text { Emrah, Doruk, and Seyit } \\
\text { showed a success rate from } 0 \% \\
\text { to } 100 \% \text { at the end of } 12 \\
\text { intervention sessions and } \\
\text { managed to maintain the } \\
\text { performance at the end of } 14 \\
\text { sessions. }\end{array}$ \\
\hline $\begin{array}{l}\text { Berry } \\
(2012)\end{array}$ & $\begin{array}{l}\text { Ten males, diagnosed } \\
\text { with ASD. }\end{array}$ & $\begin{array}{l}\text { Intervention sessions } \\
\text { held in the class } \\
\text { individually. } \\
\text { Instructions begin with } \\
\text { one to one training } \\
\text { areas. }\end{array}$ & $\begin{array}{l}\text { Single-digit addition } \\
\text { and subtraction. }\end{array}$ & $\begin{array}{l}\text { Pen, pencil and three } \\
\text { worksheets of addition } \\
\text { and subtraction } \\
\text { problems with } \\
\text { touchpoint strategy. } \\
\text { Every sheet has the } \\
\text { same difficulty level. }\end{array}$ & $\begin{array}{l}8 \text { out of } 10 \text { participants showed } \\
\text { the ability and effectiveness of } \\
\text { using touch-point and able to } \\
\text { maintain the performance. } \\
2 \text { out of } 10 \text { were not capable of } \\
\text { using touchpoint strategy and } \\
\text { require calculator as additional } \\
\text { support. }\end{array}$ \\
\hline $\begin{array}{l}\text { Waters \& } \\
\text { Boon } \\
(2011)\end{array}$ & $\begin{array}{l}\text { Three males (14 - 16), } \\
\text { secondary school } \\
\text { students, diagnosed } \\
\text { with ASD and mild } \\
\text { intellectual disabilities. }\end{array}$ & $\begin{array}{l}\text { Intervention sessions } \\
\text { held in a special } \\
\text { education class ( } 3 \times 6.5 \\
\mathrm{~m}) \text { individually. Teacher } \\
\text { and participants are sat } \\
\text { face to face during the } \\
\text { intervention sessions }\end{array}$ & $\begin{array}{l}\text { Subtraction for the } \\
\text { topic of money. }\end{array}$ & $\begin{array}{l}\text { A poster contains } \\
\text { numbers } 1 \text { to } 9 \text { with } \\
\text { touch points are used } \\
\text { and pasted on the walls } \\
\text { for instructions. } \\
\text { Worksheets of } \\
\text { subtraction problems } \\
\text { are used. }\end{array}$ & $\begin{array}{l}\text { The trend showed an increase } \\
\text { from } 6.66 \% \text { to } 75.55 \% \\
\text { (increased by } 68.88 \% \text { ), Michael } \\
\text { showed a rise from } 5 \% \text { to } 88 \% \\
\text { (increased by } 83 \% \text { ), and Alex } \\
\text { showed an increase from } \\
2.22 \% \text { to } 76 \% \text { (increased by } \\
73.77 \% \text { ). }\end{array}$ \\
\hline
\end{tabular}


Avant \& Two males and one

Heller female (7-9),

(2011) diagnosed with autism and physical

disabilities.

\section{Fletcher, Two males and one}

Boon \& female $(13-14)$,

Cihak (2010) diagnosed with ASD and mild intellectual disabilities.

held in a self-contained classroom with each of the participants individually.
Calik \& Kargin (2010)
One male and two

females (8) diagnosed with ASD and mild physical disabilities.
Intervention sessions

Basic addition

problems up to 20 .

Addition

Addition

Intervention sessions

Basic addition

held in a classroom at

the participant's school.

Table and chairs are

provided for the teacher and participants. A set of recordings is installed for data collection purposes and intervention reliability.
TouchMath number kit produced by the Innovative Learning Concept (Bullock, 1999).

Two types of worksheets, A and B with different addition problems but at the same level of difficulty. Worksheet A used a touch point strategy to solve problems.

Worksheet B used a number line strategy to solve problems.

Worksheets contain a different kind of addition problems at the same level.
Amy showed an increase from $33 \%$ to $100 \%$, Bob showed a rise from $42 \%$ to $100 \%$, Connor showed an increase from $17 \%$ to $100 \%$.

Ashley showed $30 \%$ of increment using the number line and $98 \%$ using the touch point. Robert showed $100 \%$ of increase using both number line and touch point. Ken showed $40 \%$ of increase using a number line and $100 \%$ using the touch point.

At the end of 9 sessions, Participant A showed an increase from $30 \%$ to $100 \%$, Participant B showed an increase from $40 \%$ to $100 \%$, Participant $\mathrm{C}$ showed an increase from $30 \%$ to $100 \%$. All of the participants were able to maintain performance until the control sessions were conducted. 
Cihak \& One male and two

Foust (2008) females (7-8),

diagnosed with

autism and mild

intellectual

disabilities.

Rudolph A whole class with 17

(2008)

students. 5\% with

Academically

Intellectual Gifted

(AIG), 35\% are

Exceptional Children

(EC), $60 \%$ are

Attention Deficit

Hyperactivity Disorder ADHD.

Akmanoglu Two males and one

\& Batu

(2004)

female $(6-17)$,

diagnosed with ASD.
All of the intervention sessions were conducted in a classroom at the

school of participants

and free from any

interruption.

\section{Intervention sessions}

conducted in a classroom

equipped with math

manipulative technology

and materials.
Intervention sessions for

Omer and Baris held in a

classroom at their

school. Intervention

sessions for Serap held in

a school at a university.

Each class provided a

table and chairs for the

practitioner and

participants.
Basic mathematics

addition

addition

Two types of worksheets with touch point and number line strategies for each sheet with different addition problems but at the same level of difficulty.

\section{Addition}

White cards $(10 \times 15 \mathrm{~cm})$ and black numerals written on the card. Video and stopwatch to control intervention sessions.
Travis showed an increase from $2 \%$ to $74 \%$ after 12 sessions. Ivy showed an increase from $0 \%$ to $70 \%$ after 12 sessions. Gina showed an increase from $0 \%$ to $71 \%$ after 16 sessions.

Sixteen participants showed up to $25 \%$ increment. While 1 participant was not able to use the touch point strategy has decreased by $32 \%$.

Baris showed an increase from $89 \%$ to $100 \%$. Omer showed an increase from $84 \%$ to $100 \%$. Serap showed $100 \%$ of increment. 
Simon \& One male and two

Hanrahan females (10),

(2004)

diagnosed with ASD

and low intellectual

disabilities

Strand

Involved two groups

of students at the

same level, Group I

(treatment), Group II

(control).

Group I consists of 59

students from two

schools (A: 37, B: 22).

Group II consists of 61

students from the

same school.

Wisniewski \& Four participants (3-

Smith (2002) 4) received special

education within 3 to

3 hours and a half

daily.
Intervention sessions

held in a private room on

Tuesday, Wednesday

and Friday, and free from

interruption

Intervention sessions

held in each class.

Single and double-

Intervention session held

Addition

in the participant's

classroom. digit addition

Single and double-

digits additional

problems

digit addition

Worksheets with 12 single and double-digit addition problems sorted according to the difficulty level.

Worksheets were containing 16 math problems with different difficulty levels.

A poster contains numbers one to nine with touch point are pasted in front of the class as students' references.

Worksheets contain

touch-point are used.

The video recorder was set to record

intervention sessions.
Participant A showed an increase from $47.2 \%$ to $81.9 \%$.

Participant B showed an

increase from $1.4 \%$ to $92.56 \%$.

Participant $C$ showed an

increase from $74 \%$ to $97.2 \%$.

Group I showed the ability to answer additional problems with $80 \%$ of correct responses, while Group II showed the ability to solve the additional problems with $40 \%$ of correct responses.

Participant 1 showed an increase of $85 \%$ to $100 \%$. Participant 2 showed a decrease of $98 \%$ to $95 \%$. Participant 3 showed the same achievement (100\%) before and after the intervention. Participant 4 showed an improvement of $23 \%$ to $93 \%$. 
Scott (1993) Three participants (8) diagnosed with ASD and mild intellectual disabilities.
Intervention sessions held in a library's class. Each session runs for 2 hours per day.
Single, double and triple digit addition and subtraction.
Twenty-four worksheets (single digit: 8; doubledigits: 8 ; triple-digits: 8 ), a poster of touch points posted on the wall for participants' references.
Participant 1 showed an increment of $96 \%$ within three days of intervention sessions. Participant 2 showed an increase of $100 \%$ within two days of intervention sessions. Participant 3 showed an increment of $94 \%$ within one day of intervention session.
Thornton, Sixty-one participants Jones \&

Toohey (1983)
Intervention session held Single-digit addition in a group of 10 students and subtraction for each group. 
INTERNATIONAL JOURNAL OF ACADEMIC RESEARCH IN BUSINESS AND SOCIAL SCIENCES

Vol. 9, No. 3, March, 2019, E-ISSN: 222 2-6990 @ 2019 HRMARS

\section{The effectiveness of touch points intervention in improving ASD's student mathematical achievement}

There are numerous researches on new and innovative interventions such as the TouchMath (Bullock et al., 1989), also known as touch points. Among them are the studies conducted by Avant and Heller (2011), Berry (2012), Calik and Kargin (2010), Cihak and Foust (2008), Rudolph (2008), Simon and Hanrahan (2004), Waters and Boon (2011), Wisniewski and Smith (2002), and Yıkmış (2016) which aims to examine the effectiveness of touch points intervention for children with ASD in solving fundamental mathematical problems for addition and subtraction topics. These studies showed that touch point techniques were an effective strategy in helping children with ASD to build and improve basic mathematical problem-solving skills. While Rudolph (2008) suggested, touch points intervention continues to be carried out in helping to address the problem of students with low capability in mastering numeracy basis.

The previous studies showed the touch point method have focused on addition and subtraction with one and two digits only. Thus, there has been limited research using the touch point method to develop addition and subtraction for three digits and above. The method also has not been conducted to build multiplication and division skills. With the effectiveness of mathematical intervention using touchpoint method in enhancing the addition and subtraction skills as evidenced Table 1, it is recommended that this touchpoint method should be utilized in multiplication and division too.

\section{CONCLUSION}

The purposes of this systematic literature review are to identify the characteristics of participants, findings, and suitability of touch point intervention based on the characteristics of children with ASD. All of the included studies used touchpoint strategy to children with ASD that focused on basic mathematical skills such as one and two digits addition and subtraction. The findings expanded the literature by evaluating the quality of the studies, identifying participants' characteristics, findings and suitability of touch point intervention based on the characteristics of children with ASD. By all counts and with proven research findings, touchpoints method is considered by many educators to have been among the excellent teaching aid to help students in progressing number skills.

\section{Acknowledgment}

This work is part of the project that has received funding from the Ministry of Education under the Fundamental Research Grant Scheme (FRGS/1/2017/SS05/UKM/02/2).

\section{REFERENCES}

Akmanoglu, N. \& Batu, S. 2004. Teaching Pointing to Numerals to Individuals with Autism Using Simultaneous Prompting. Education and Training in Developmental Disabilities.

APA. 2013. American Psychiatric Association. Diagnostic and Statistical Manual of Mental Disorders. Asiahwati, A. 2015. Tahap Numerasi dan Strategi Penyelesaian Masalah Dalam Bidang Nombor Bagi Pelajar Lepasan Menengah. Tesis Dr. Fal. Universiti Sains Malaysia. 
Avant, M. J. T. \& Heller, K. W. 2011. Examining the effectiveness of touchmath with students with physical disabilities. Remedial and Special Education 32(4): 309-321.

Aydemir, T. 2015. A Review of the Articles about TouchMath. Procedia - Social and Behavioral Sciences 174: 1812-1819.

Berry, D. 2012. The effectiveness of the TouchMath curriculum to teach addition and subtraction to elementary aged students identified with autism. San Bernadino, CA.

Besler, F. \& Kurt, O. 2016. Effectiveness of video modeling provided by mothers in teaching play skills to children with autism. Educational Sciences: Theory \& Practice 16(1): 209-230.

Browder, D. M., Jimenez, B. A. \& Trela, K. 2012. Grade-aligned math instruction for secondary students with moderate intellectual disability. Education and Training in Autism and Developmental Disabilities 47(3): 373-388.

Burney, S. L. 2015. Interventions to Improve Student Achievement in Mathematics for Middle School Students with Autism. Georgia College and State University.

Burton, C. E., Anderson, D. H., Prater, M. A. \& Dyches, T. T. 2013. Video self-modeling on an ipad to teach functional math skills to adolescents with autism and intellectual disability. Focus on Autism and Other Developmental Disabilities 28(2): 67-77.

Calik, N. C. \& Kargin, T. 2010. Effectiveness of the touch math technique in teaching addition skills to students with intellectual disabilities. International Journal of Special Education 25(1): 195204.

Cihak, D. F. \& Foust, J. L. 2008. Comparing number lines and touch points teach addition facts to students with Autism. Focus on Autism and Other Developmental Disabilities 23(3): 131-137.

Fletcher, D., Boon, R. T. \& Cihak, D. F. 2010. Effects of the touchmath program compared to a number line strategy to teach addition facts to middle school students with moderate intellectual disabilities. Education and Training in Autism and Developmental Disabilities.

Geary, D. C. 2011. Consequences, characteristics, and causes of mathematical learning disabilities and persistent low achievement in mathematics. Journal of Developmental \& Behavioral Pediatrics 32(3): 250-263.

Geiger, V., Merilyn, G., Shelley, D., Helen, F. \& Anne, B. 2013. Exploring the demands and opportunities for numeracy in the Australian Curriculum: English. Mathematics Education Research Group of Australasia, pg. 330-337. Melbourne.

Gevarter, C., Bryant, D. P., Bryant, B., Watkins, L., Zamora, C. \& Sammarco, N. 2016. Mathematics Interventions for Individuals with Autism Spectrum Disorder: A Systematic Review. Review Journal of Autism and Developmental Disorders 3(3): 224-238.

Holifield, C., Goodman, J., Hazelkorn, M. \& Heflin, L. J. 2010. Using self-monitoring to increase attending to task and academic accuracy in children with autism. Focus on Autism and Other Developmental Disabilities 25(4): 230-238.

Jordan, N. C., Kaplan, D., Ramineni, C. \& Locuniak, M. N. 2009. Early math matters: kindergarten number competence and later mathematics outcomes. Developmental Psychology 45(3): 850867.

Jowett, E. L., Moore, D. W. \& Anderson, A. 2012. Using an iPad-based video modeling package to teach numeracy skills to a child with an autism spectrum disorder. Developmental Neurorehabilitation 15(4): 304-312. 
King, S. A., Lemons, C. J. \& Davidson, K. A. 2016. Math interventions for students with autism spectrum disorder: A best-evidence synthesis. Exceptional Children 82(4): 443-462.

Lemons, C. J., Powell, S. R., King, S. A. \& Davidson, K. A. 2015. Mathematics interventions for children and adolescents with Down syndrome: A research synthesis. Journal of Intellectual Disability Research 59(8): 767-783.

McCrimmon, A. W. \& Yule, A. E. 2017. Clinical reasoning in the assessment and planning for intervention for Autism Spectrum Disorder. Canadian Journal of School Psychology 32(1): 5972.

O'Malley, P., Lewis, M. E. B., Donehower, C. \& Stone, D. 2014. Effectiveness of Using iPads to Increase Academic Task Completion by Students with Autism. Universal Journal of Educational Research 2(1): 90-97.

Ping Yee, L. \& Mohd Ali, M. 2008. Amalan program intervensi awal kanak-kanak autistik mengikut perspektif ibu bapa. Jurnal Pendidikan 33: 19-33.

Rudolph, A. C. 2008. Using Touch Math to Improve Computations. North Carolina.

Sarama, J. \& Clements, D. H. 2008. Mathematics in early childhood. National Council of Teachers of Mathematics.

Satsangi, R., Bouck, E. C., Taber-Doughty, T., Bofferding, L. \& Roberts, C. A. 2016. Comparing the Effectiveness of Virtual and Concrete Manipulatives to Teach Algebra to Secondary Students with Learning Disabilities. Learning Disability Quarterly 39(4): 1-14.

Schmidt, C. \& Bonds-raacke, J. 2013. The effects of video self-modeling on children with Autism Spectrum Disorder. International Journal of Special Education 28(3): 121-132.

Scott, K. S. 1993. Multisensory Mathematics for Children with Mild Disabilities. Special Education Journal 4(2): 97-111.

Shanley, L., Cary, M. S., Clarke, B. \& Jungjohann, K. 2013. Teaching early knowledge of whole number concepts through technology: findings from a feasibility study of an iPad delivered kindergarten mathematics intervention.

Simon, R. \& Hanrahan, J. 2004. An evaluation of the touch math method for teaching addition to students with learning disabilities in mathematics. European Journal of Special Needs Education 19(2): 191-209.

Siti Rahaimah, A. 2014. Analisis Kefahaman Numerasi Murid Sekolah Rendah. Universiti Pendidikan Sultan Idris.

Spooner, F., Root, J. R., Saunders, A. F. \& Browder, D. M. 2018. An Updated Evidence-Based Practice Review on Teaching Mathematics to Students With Moderate and Severe Developmental Disabilities. Remedial and Special Education 1-16.

Strand, L. 2003. The TouchMath Program and It 's Effect on the Presented by. National Council of Teachers of Mathematics 14(3).

Su, H. F. H., Lai, L. \& Rivera, H. J. 2012. Effective Mathematics Strategies for Pre-School Children with Autism. Australian Primary Mathematics Classroom 17(1): 25-30.

Thornton, C. A., Jones, G. A. \& Toohey, M. A. 1983. A Multisensory Approach to Thinking Strategies 14(3): 198-203.

Waters, H. E. \& Boon, R. T. 2011. Teaching money computation skills to high school students with mild intellectual disabilities via the TouchMath@ Program: A multi-sensory approach. 
Education and Training in Autism and Developmental Disabilities 46(4): 544-555.

Whalon, K. J., Conroy, M. A., Martinez, J. R. \& Werch, B. L. 2015. School-Based Peer-Related Social Competence Interventions for Children with Autism Spectrum Disorder: A Meta-Analysis and Descriptive Review of Single-Case Research Design Studies. Journal of Autism and Developmental Disorders 45(6): 1513-1531.

Wisniewski, Z. G. \& Smith, D. 2002. How Effective is Touch Math?

Yıkmış, A. 2016. Effectiveness of the Touch Math Technique in Teaching Basic Addition to children with Autism. Educational Sciences: Theory \& Practice 16(3): 1005-1025.

Zajic, M. C., Mclntyre, N., Swain-Lerro, L., Novotny, S., Oswald, T. \& Mundy, P. 2016. Attention and written expression in school-age, high-functioning children with autism spectrum disorders. Journal of Autism (1-14): 1-14. 